Revista de Literatura,

História e Memória

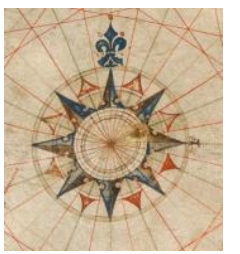

Dossiê: Manifestações de re-existência: a literatura em tempos de repressão

ISSN 1983-1498

VOL. 16 - $\mathbf{N}^{\circ} 27$ - 2020

U N I O E S T E / CA S C A V E L - p. 201-225

\title{
ÚRSULA NA CONTRAMÃO DO ROMANTISMO BRASILEIRO \\ UM ENSAIO DE ESTÉTICA COMPARADA
}

\author{
Úrsula against the grain of brazilian romanticism. \\ an essay of comparative aesthetics
}

Felipe Vale da Silva ${ }^{1}$

RESUMO: O artigo analisa as intertextualidades de Úrsula (1859), de Maria Firmina dos Reis, ressaltando como a autora se valeu de princípios estéticos centrais do romantismo europeu para fins próprios de representação. Um tratamento detido do capítulo 1 do romance mostra uma substituição clara dos imperativos da cor local de Gonçalves de Magalhães e José de Alencar pela representação do que o Império do Brasil realmente era: mais do que um cenário inócuo de fauna e flora exuberantes, era uma terra historicamente manchada pela escravidão e pela tirania dos mandatários. Assim, Firmina dos Reis escreve o primeiro romance antiescravista brasileiro a partir dos desafios alencarianos de representação nacional; seu trabalho minucioso com teorias e ideias em curso a tornam uma inteligência inovadora dentro do romantismo.

PALAVRAS-CHAVE: Romantismo; Maria Firmina dos Reis; Antiescravismo; Cor local; Intertextualidade.

ABSTRACT: The article analyzes the intertextualities within Úrsula (1859) by Maria Firmina dos Reis, highlighting how the author employed central aesthetic principles of European romanticism so as to achieve her own representational goals. A close reading of chapter 1 of this novel reveals a clear reconsideration of the imperatives of the local color school (of Gonçalves de Magalhães and José de Alencar), replacing them by the representation of what the Brazilian Empire really was: more than an innocuous scenery of exuberant fauna and flora, it was a land historically tainted by slavery and the tyranny of its leaders. Thereby, Firmina dos Reis writes the first Brazilian anti-slavery novel against the grain of the Alencarian challenges of national representation; her meticulous work with theories and ideas in progress renders her an innovative intelligence within romanticism.

KEYWORDS: Romanticism; Maria Firmina dos Reis; Antislavery; Local color school; Intertextuality.

O romantismo foi um divisor de águas na história cultural em vários sentidos. As novas tecnologias de divulgação do século XVIII doaram à arte literária um poder de disseminação de ideias nunca antes vistos. Com o fenômeno da nova esfera pública, seus modos de difusão potencializaram-se; além disso, possibilidades inéditas de trânsito se abriam aos habitantes de países e reinos europeus - naquela época do navio a vapor e alastramento de uma primeira malha rodoviária entre grandes cidades da Europa, viajava-se mais e em menos tempo..$^{2}$ No contexto, Madame de Stäel foi uma figura onipresente, empenhada na

\footnotetext{
${ }^{1}$ Doutor em Letras (Literatura Alemã) pela Universidade de São Paulo e Martin-Luther-Universität HalleWittenberg. Desenvolveu pós-doutorado em afroamericanística pela Universidade Federal de Goiás.

${ }^{2}$ Ainda que viagens fossem dispendiosas, lentas e perigosas. Talvez o mais completo tratamento do entusiasmo
} 
constituição do romantismo como um fenômeno internacional.

Graças a de Stäel, estudar a era romântica nos coloca em contato com um quadro dinâmico de trocas de influências entre artistas de países diversos. Ela estabeleceu contato entre algumas figuras pivotais, relatando visitas pessoais a outras com tanto êxito, que temos a impressão de que todos os escritores relevantes da Europa se conheciam de uma forma ou de outra. Após anos na estrada, ela compilou anotações sobre a cena literária alemã e deu-lhes o título D’Allemagne (1813), livro que difundiu o romantismo na França, Inglaterra e Portugal. Essa história continua - parte do fascínio que os românticos provocam em quem os pesquisa advém da impressão que trabalhavam em um esforço unificado, para além das barreiras de nacionalidade, visando a construção de um órgão renovado de inteligência afetiva e social que hoje chamamos de literatura moderna.

Foi no mesmo contexto que Maria Firmina dos Reis compôs sua obra do outro lado do Atlântico, na cidade de São Luís/MA. O seu, porém, foi um caso à parte. A falta de registros de época nos impede sustentar que essa professora escolar tenha contribuído com o grande projeto do Romantismo internacional de forma autoconsciente, trabalhando conjuntamente com seus conterrâneos mais famosos — os irmãos Azevedo, Sousândrade, Gonçalves Dias — ; isso explicaria a divulgação tímida de seu romance Úrsula: romance original brasileiro (1859) e a entrada tardia nos currículos de literatura em nosso país.

O que sabemos de Firmina dos Reis é fruto do esforço de pesquisa da década de 1970 em diante. ${ }^{3}$ A rigor, por ser tardia, sua fortuna crítica é tão incipiente quanto a de qualquer escritora contemporânea a nós. A pesquisa magistral de Rafael Balseiro Zin (2019, p. 23 et seq) resume o que se tem de material documentado a respeito dessa figura e será retomada aqui para fins de contextualização: o contato de Firmina dos Reis com as letras acompanhou sua atuação na imprensa local e na atuação como professora. Publicou, em 1859, seu romance sob a alcunha "Uma Maranhense", talvez inconsciente de ser a primeira mulher romancista do Brasil, a inauguradora das letras afro-brasileiras, além de conferir o primeiro retrato da escravidão brasileira a partir de personagens cativos. No romance de estreia, sua persona literária é apresentada como uma diletante — "mulher, e mulher brasileira, de educação acanhada e sem o tracto e a conversação dos homens illustrados, que aconselham, que discutem e que corrigem" (REIS, 1975 [1859], p. 5). Apesar da introdução minguada, quase

pelas novas tecnologias de locomoção na virada do século XVIII para o XIX seja o livro de Bruno Preisendörfer (2015, sobretudo p. 58-62, 75-84). Preisendörfer interpreta a "febre por viagens" de jovens e intelectuais da época, em busca de novos estímulos e experiências transfiguradoras, como uma moda cultural da era romântica (op. cit., p. 83).

${ }^{3}$ Ver documentação detalhada em Zin (2019, p. 29-30). 
autoindulgente, a autora recebe reconhecimento por parte dos resenhistas (ver ZIN, 2019, p. 41-45). Persiste em sua carreira artística até meados de 1880, dedicando-se a criação de canções folclóricas, contos e poemas.

Ao apresentar-se como diletante, surge o primeiro estranhamento frente à ideia de uma Firmina dos Reis romântica. Diletantismo foi um conceito discutido ad nauseam por teóricos alemães desde Johann Georg Sulzer e, mais celebremente, por Johann Wolfgang Goethe, quando desenvolvia suas teorias do Classicismo de Weimar para se opor a tudo o que os românticos alemães vinham fazendo. Ao seu ver, os românticos pecavam por crer que qualquer pessoa trazia em si, potencialmente, o gérmen da genialidade; isso só promoveria um apagamento dos limites entre o talento e o mais completo amadorismo que, no contexto alemão, vinha causando um atraso no progresso das artes e da cultura em uma sociedade ameaçada pelo obscurantismo (NIEDERMEIER, 2004, p. 222). Mediante essa polêmica, Goethe se tornou o grande detrator do romantismo, inaugurando uma cisão na literatura alemã. Novalis, seu principal desafeto, parece ter sido o defensor mais eloquente dessa nova concepção do gênio espontâneo ${ }^{4}$ — ao encontrar traços de genialidade nas canções populares, no povo simples e nos arroubos apaixonados da juventude, diletantismo se tornou um termo proibido do léxico do romantismo.

Mais uma vez, é razoável esperarmos de Firmina, que cresceu devorando livros e "participou ativamente da vida intelectual maranhense" (TELLES, 1997, p. 412), familiaridade com a polêmica em questão. É plausível que, ao evocar uma categoria que os românticos não validavam, estivesse justificando a escrita daquele livro como uma compactuadora confessa da nova estética, apesar dos eventuais juízos que a rebaixassem como diletante em função de sua posição inédita de mulher escritora no Brasil.

Não é o que sua fortuna crítica defende: Simões (2012, p. 9) assume o tom do prefácio como genuíno, ao passo que Zin (2019, p. 25) o toma como uma estratégia de jogar com os preconceitos do público relativo a autoras femininas, evitando romper bruscamente com as hierarquias da sociedade brasileira à época que, afinal, a colocavam em uma posição desfavorável. A leitura da versão fac-símile de Úrsula, porém, mostra traços estilísticos bastante particulares por parte da autora - aqui reside o espaço para uma terceira via interpretativa do trecho. Contra a norma culta do português atual, Firmina dos Reis quase sempre se vale da vírgula antes do emprego do pronome relativo "que", seja para designar função explicativa ou restritiva. ${ }^{5}$ Desta feita, o trecho seguinte -

\footnotetext{
${ }^{4}$ Ver um tratamento mais detido em Silva (2019a, p. 77 e 79, nota 5).

${ }^{5}$ Cito alguns dos muitos casos onde "que" inicia uma oração subordinada restritiva mas, contra a norma culta
} 
mulher, e mulher brasileira, de educação acanhada e sem o tracto e a conversação dos homens illustrados, que aconselham, que discutem e que corrigem (REIS, 1975, p. 5).

— é, em um texto firminiano, um trecho ambíguo. Como a vírgula entre "ilustrados" e "que" não diferencia o pronome relativo iniciando uma oração subordinada explicativa (e diz: "os homens ilustrados, que [em geral] aconselham, discutem e corrigem") daquele iniciando uma subordinada restritiva ( "os homens ilustrados [específicos] que aconselham, discutem e corrigem"), temos uma impasse interpretativo.

O segundo caso, evidentemente, é aquele que nos interessa. Ele conferiria um tom irônico ao prefácio, quebrando a imagem de uma autora fragilizada, insegura de sua pena. Em uma reformulação para a norma culta atual, é como se a narradora se apresentasse como uma "mulher brasileira [...] sem o trato e a conversação dos homens ilustrados que aconselham, que discutem e que corrigem [tudo aquilo que leem]". Antes de uma fórmula de diminuição de si, teríamos aqui uma fórmula de diferenciação qualitativa de uma suposta amadora contra os "illustrados" cheios de juízos prontos — juízos estes que não a impediram de escrever e publicar sua obra, antes de tudo.

Decerto, há certa fragilidade neste argumento, que surge aqui como um mero salto interpretativo: o argumento é fruto de especulação e se apoia em um desvio gramatical da autora. No entanto, servirá de ponto de partida para a sugestão de uma Firmina melhor versada no estilo e arcabouço cultural de sua época do que geralmente se assume; ele será acompanhado de melhores comprovações que nos guie por tal caminho.

A expectativa da presente abordagem é a de romper o velho pressuposto: quando se fala de Firmina dos Reis como uma romântica, implica-se que a professorinha isolada no Maranhão absorveu a estética de sua época como que por osmose. Argumentarei como ela fez mais do que absorver e repetir fórmulas dos livros que leu; antes, transformou ideias estéticas vindas da Europa em um poderoso meio de representação da realidade brasileira, distinto de demais autores da época.

atual, é precedido de vírgula: "o homem que assim falava era um pobre, que ao muito parecia contar vinte e cinco anos" (op. cit., p. 14); "permitti que vos leve á fazenda, que ali vedes" (p. 17); "Ursula [...] vinha desempenhar á cabeceira desse leito de dores os cuidados, que exigia o penoso estado do desconhecido (p. 2223), "era uma d'essas tardes, que só Bernardin de Saint-Pierre soube pintar" (p. 124). Nas edições do romance mais recentes, ortografia e sintaxe foram modernizadas; tal processo de normatização, como vemos no caso do prólogo, necessariamente envolveu uma intepretação por parte de editores de qual função o pronome desempenhava em um ou outro caso. Não necessariamente a versão modernizada corresponde aos intentos expressivos da autora, sobre os quais só nos resta especular. Por esse motivo, citaremos somente o texto da primeira impressão do texto comissionada pela autora, a partir da versão fac-similar organizada por Horácio de Almeida (REIS, 1975). 
A maior dificuldade para executar tal projeto comparatístico advém da impossibilidade de respondermos: qual contato Firmina, de fato, teve com autores de fora? Quais línguas podia entender? De onde vieram suas ideias, seu antiescravismo e noções de protagonismo negro dentro de uma tradição literária que ainda engatinhava no processo de integração de perspectivas minoritárias? Nossos caminhos parecem de antemão bloqueados por falta de uma documentação esclarecedora dessas perguntas elementares. Resta, porém, a via mais simples: seguir as dicas e intertextos que a própria autora deixou em sua obra. Arriscarei algumas abordagens partindo de uma análise de referências, evitando desde já evocar uma tendência predominante na crítica contemporânea, contra as quais nos alerta Ana Flávia Magalhães Pinto (2018, p. 224): a saber, aquela que atribui a relevância de Firmina unicamente em função de seu lugar de fala como mulher negra que porventura pôde se educar e escrever o primeiro romance feminino brasileiro. Tal tendência não é problemática em si, é claro, mas muitas vezes faz pesquisadores a abrirem mão da análise detida das obras relegadas pela autora, satisfazendo-se com juízos antigos. Como consequência, parece haver um esforço desnecessário por se justificar o estilo folhetinesco de Firmina dos Reis, a simplicidade de suas personagens e até o pessimismo de seu retrato do Brasil - como se essas fossem falhas de percurso, e não características constitutivas que a aliam a outros grandes pensadores do Brasil: Machado de Assis, Luís Gama e Lima Barreto.

Aqui, Firmina não precisa ser justificada. Se nossa tese estiver certa, basta lê-la em contraste com teorias em curso naquele ambiente de trânsito de ideias para que os vapores de amadorismo que a rodeiam se dissipem. É o que faremos no tópico seguinte.

\section{O DIVINO NA NATUREZA: ÚRSULA, CAPÍTULO I, PARÁGRAFOS 1-10}

O capítulo inicial de Úrsula inicia com uma longa descrição de uma paragem litorânea brasileira. Por três páginas no texto original, a narradora desenvolve um quadro para parecer atender às advertências de nosso pioneiro em romantismo, Gonçalves de Magalhães, e que já conhecemos bem: Magalhães pede uma poesia renovada, movida pelo "instinto oculto" dos brasileiros, que se deixe moldar pelo ambiente natural. ${ }^{6}$

Na condição de estudante em Paris, Magalhães tomou para si a tarefa de divulgar para seus conterrâneos a grande novidade das letras europeias: o romantismo ia muito além de uma moda literária passageira, provando-se como uma postura filosófica inédita ante o labor

\footnotetext{
${ }^{6}$ Ver o Ensaio sobre a história da literatura do Brasil, MAGALHÃES, 1978 [1836], p. 147.
} 
literário. Nele se "constitui o momento inaugural da literatura como produção de sua própria teoria $[. .$.$] Com tal gesto, ele dá abertura a época de crítica à qual ainda pertencemos". 7$ Onde se desenvolveu, foi calorosamente recebido como um modo criativo que permitia a produtores de cultura escreverem seus livros sem terem de se curvar a imperativos do passado: das tradições, dos clássicos, da religião ou mesmo da racionalidade fria. Daí vem, em partes, o grande entusiasmo de Magalhães e seus comparsas perante possibilidades inéditas de representação artística. A prática literária derivava de teorias - algumas de fundo estético, outras voltadas aos projetos de identidade nacional, outras de interesses pessoais dos escritores - e dessa sina não fugiram aqueles primeiros românticos brasileiros que, hospedados na capital francesa, também escreveram teorias antes de começar a escrever literatura: a Revista Brasiliense de Ciências, Letras e Artes lhes serviu de veículo de divulgação.

Magalhães e seus colegas se debruçaram sobre uma busca genealógica de temas que dividiam a inteligência brasileira da portuguesa. Tratava-se de uma declaração da independência simbólica, digamos, ao menos de divorciar o espírito dos dois povos. Enquanto românticos ibéricos delineavam a retomada literária de uma época de supostas glórias medievais (Almeida Garrett já era um escritor ativo nos anos 1820), Magalhães se viu confrontado por um dilema: na condição de país colonizado, o Brasil falante de português não tinha um passado glorioso a ser resgatado a partir de registros empoeirados. Portanto, sua aposta inicial foi a de apelar para a natureza e os seres naturais brasileiros - na perspectiva etnocêntrica de virtualmente todos nossos intelectuais à época, aqui se encontraria o indígena. Somente a dimensão natural funcionaria tal qual "um diferencial em relação ao velho continente, constituindo um elemento que contribuía para a formação de uma identidade própria” (CARNEIRO, 2011, p. 498).

Optar pela natureza trouxe implicações problemáticas sobre as quais José Alencar, já na geração de Firmina dos Reis, construiu sua polêmica contra Magalhães. ${ }^{8}$ Segundo Alencar, a base para a poesia de Magalhães era fraca. Por contar com um senso místico, mas intraduzível, de brasilidade, facilmente se perdia em abstrações infrutíferas, haja vista o poema épico A Confederação dos Tamoios (1856). Nele, Magalhães narra a importante guerra colonial travada entre 1554 e 1567 ao longo do Vale do Paraíba, e que contou com a

\footnotetext{
7 " [...] [it] constitutes the inaugural moment of literature as production of its own theory [...] With this gesture, it opens the critical age to which we still belong" (LACOUE-LABARTHE; NANCY, 1988, p. xxiii). Esta e demais traduções são de autoria do articulista, salvo quando indicado.

${ }^{8}$ A polêmica realizou-se na Revista Minerva (no Rio de Janeiro, em 1846), posteriormente reunida sob o título Cartas sobre a Confederação dos Tamoios. Baseamo-nos na importante documentação de Vinícius Carneiro (2011) e na versão reunida das cartas publicada pelo próprio Alencar (1846).
} 
participação de figuras históricas centrais (Mem de Sá, Duarte da Costa, Hans Staden, Estácio de Sá) do lado dos genocidas. O objetivo era escravizar os nativos para mover a máquina colonial recém-instalada na região. No final, os indígenas resistiram ao ataque dos portugueses e, com o episódio da Paz de Iperoig, os povos escravizados foram libertos (PERRONE-MOISÉS; SZTUTMAN, 2010, p. 419-420).

Trata-se da primeira vitória autóctone contra a escravidão; se inicialmente podemos pensar que a luta gigantesca serviria de prelúdio para "os grandes acontecimentos [os quais] servem de prólogo ás [sic] revoluções de um povo, ás [sic] épocas históricas de uma nação" (ALENCAR, 1856, p. 15), Magalhães termina por obliterar boa parte das figuras históricas presentes no conflito (p. 54-55). Logo esquece do conflito civilizatório, voltando-se a uma historieta de amor trivial (p. 5). O resultado foi uma narrativa repleta de 'cor local', mas fria e desconexa:

[...] o autor não aproveitou a idéa mais bella da pintura; o esboço historico d'essas raças extinctas, a origem d'esses povos desconhecidos, as tradições primitivas de indigenas, davão por si só materia a um grande poema, [...] $\mathrm{Na}$ minha opinião o Sr. Magalhães teria feito melhor se abrisse o seu poema pela conselho dos chefes tamoyos que tem que tem lugar no 2 . $^{\circ}$ canto; e depois, explicando a causa da confederação, fizesse valer o sentimento nacional, a liberdade, e o captiveiro dos índios (ALENCAR, 1859, p. 8-10).

O instinto de nacionalidade não é nada se não for expresso em conteúdos palpáveis, em descrições tangíveis de nossa natureza e na releitura de episódios históricos formadores de quem somos como brasileiros - é este o alerta que José de Alencar emitiu treze anos antes de Úrsula, e que também serviu de estopim para a produção de seus próprios romances indianistas (ver CARNEIRO, 2011, p. 502 et seq). Os resultados de Alencar, certamente, devem ser julgados: ele foi aquele que apelou para rigor no retrato do Brasil (com estudo de sua flora, fauna e etnografia) mas povoou o cenário do capítulo IV d'O Guarani com um tigre - certamente uma besta majestosa, mas que habita a longínqua Ásia. O anacronismo latente, inúmeras falsificações de etimologia de palavras tupi e retrato dos indígenas como se fossem cavaleiros medievais europeus mostram que Alencar se interessava pela brasilidade para fins de exotismo.

Aqui voltamos a uma questão crucial: será que no primeiro capítulo de Úrsula, Firmina dos Reis se mostrou alheia aos debates estético-ideológicos da intelectualidade brasileira, devendo, como sugeriu no prefácio do livro, ser desculpada como uma ignorante em assuntos de literatura? Analisemos trechos dos três parágrafos iniciais: 
São vastos e bellos os nossos campos; porque innundados pelas torrentes do inverno simelhan o occeano em bonançosa calma-branco lençol de espuma, que não ergue marulhadas ondas, nem brame irado, ameaçando insano quebrar os limites, [sic] que lhe marcou a omnipotente mão do rei da creação. [...] os campos são qual vasto deserto, majestoso e grande como o espaço, sublime como o infinito.

E a sua belleza é amena e doce, e o exíguo esquife, que vae cortando as suas aguas hybernaes mansas e quedas, e o homem, que sem custo o guia, e que sente vaga sensação de melancholico enlevo, desprende com mavioso acento um canto de harmoniosa saudade, despertado pela grandesa d'essas aguas, que sulca (REIS, 1975, p. 7, meus grifos).

Os trechos grifados referem-se a conceitos-chave do romantismo internacional, alguns dos quais trataremos a seguir. Notemos, antes de tudo, uma diferença elementar às propostas de Magalhães e Alencar: aqui apresenta-se um quadro de integração do homem ao todo da natureza, que simultaneamente espelha a face do divino. Não se trata de representar o indígena, mas um ser humano especulativo, desprovido de singularidade (ele, afinal, é identificado apenas como "o homem"), que retoma contato com a infância da raça humana. A segunda personagem no quadro é o "Rei da criação" (p. 7), "Auctor da naturesa" (p. 9), uma força ausente, mas intuída pelo homem primevo por força do equilíbrio estabelecido nos elementos naturais.

Aqui não encontramos descrições da paisagem natural que não sejam acompanhadas por uma ponderação dos sentimentos processados no íntimo do sujeito, imerso na exuberância daquele cenário: "expande-se-nos o coração quando calcamos sob os pés a herva reverdecida" (p. 8), temos "lindas flores tropicaes, cuja fragancia arrouba" (p. 8) e, no que talvez seja o trecho mais revelador, "a vista expande-se e deleita-se" (p. 9). Nesta fórmula eloquente, o mesmo sujeito da oração, "a vista", desempenha duas ações simultâneas: expande-se revela aos olhos humanos seu prolongamento por um amplo espaço - e simultaneamente causa deleite no peito humano. A dimensão física é seguida da emotiva nesse encadeamento discricional; é como se o sublime da natureza fosse calculado para o deleite humano. A narradora, portanto, está lidando com uma epistemologia de contemplação da natureza bastante específica, aquela que a filosofia da história romântica atribuiu a um suposto estágio de infância da humanidade, onde o humano gozava de unio mystica com o cosmos e a divindade. A paisagem se tinge das afecções humanas, confluindo para uma unidade harmônica onde o tempo histórico não existe: a vida segue um só fluxo de equilíbrio ideal entre os elementos. 
Depois, mudou-se já a estaçao; as chuvas desappareceram, e aquelle mar, que viste, desappareceo com ellas, voltou ás nuvens formando as chuvas do seguinte inverno, e o leito, que outr'ora fora seo, transformou-se em verde e humido tapete, matisado pelas brilhantes e lindas flores tropicaes, cuja fragancia arrouba e só tem por apreciador algum desgarrado viajor (REIS, 1975, p. 8).

Comparemos o trecho com outra célebre descrição natural do pré-romantismo:

Quando a bruma do vale se levanta à minha volta, e o sol altaneiro descansa sobre a abóbada escura e impenetrável da minha floresta, e apenas alguns escassos raios deslizam até o fundo do santuário, ao passo em que eu, deitado entre a relva alta, na encosta de um riacho, descubro no chão mil plantinhas desconhecidas... Quando sinto mais perto de meu coração a existência desse minúsculo mundo que formiga por entre a relva, essa incontável multidão de ínfimos vermes e insetinhos de todas as formas e imagino a presença do Todo-Poderoso, que nos criou à sua imagem e semelhança, [...] Ah, meu amigo, quando o mundo infinito começa a despontar assim ante meus olhos [...], então suspiro profundamente e penso: $\mathrm{Ah}$ ! Pudesses tu voltar a expressá-lo, pudesses tu exalar o sentimento e fixar no papel aquilo que vive em ti com tanta abundância e tanto calor, de maneira que o mesmo papel pudesse se fazer o espelho de tua alma, como tua alma é o espelho do Deus infinito! (GOETHE, 2001, p. 14-15. O texto original consta em GOETHE, 2006, p. 14).

O trecho acima, passagem bastante conhecida d'Os Sofrimentos do jovem Werther de Goethe, expressa uma epistemologia próxima à do início de Úrsula. A frustração do sujeito de enunciação advém do poder intuir o maravilhoso na natureza, mas não conseguir processá-lo tal qual um ser integrado à totalidade do cosmos. O "homem" que aparece no início do romance firminiano - e nunca mais voltará à narrativa - logo revela uma entidade estranha àquele ambiente. Para o viajante transitando por paragens no trecho supracitado, a imersão na natureza significa a "hora derradeira do seu triste viver" (op. cit., p. 8). Como Werther, ele só está protegido do desamparo existencial enquanto for capaz de abstrair sua condição normal de vida.

Essa personagem ansiosa por uma reintegração com a natureza é produto corriqueiro da criatividade romântica; ela deriva de uma convicção filosófica de que aquela harmonia perdida entre humanidade e natureza só pode ser resgatada de forma incompleta, como tema da poesia. O órgão mais adequado para tal resgate seria, assim, uma linguagem que se adaptasse à movimentação misteriosa da vida, onde metáforas substituem conceitos (SAFRANSKI, 2010, p. 23). Nesse sentido, o ímpeto pelo resgate de uma veia poética originária foi acompanhado, já nos pré-românticos, pelas primeiras teorias sobre as origens da linguagem poética dos antigos. O tema foi particularmente caro a Jean-Jacques Rousseau e a 
Johann Gottfried Herder, propositores da hipótese (bastante inusitada) de que o linguajar da poesia lírica veio antes da linguagem regulada com a qual nos comunicamos. Antes de conversar, o homem das matas cantou - supostamente, tendo um repertório limitado de palavras para se expressar, começou a se valer de metáforas aproximativas para designar tudo que lhe fosse desconhecido: algo como a formulação "branco lençol de espuma" que vemos na narrativa de Firmina para designar o oceano (p. 7) e abundam somente nesse primeiro quadro do romance - é válido pontuar —, dando espaço para uma linguagem objetiva a partir do parágrafo nono (p. 9 et seq). Desta curiosa adaptação frente ao despreparo lexical derivaria a sensibilidade lírica dos povos primitivos a qual, para Herder, vinha se perdendo como preço pela modernização da cultura. ${ }^{9}$

Notemos os termos de Firmina dos Reis: os hinos dos primeiros humanos, "cujos acentos perdem-se no espaço, são como notas d'uma harpa eólia, arrancadas pelo roçar da brisa" (op. cit., p. 8). Isto é dizer: para eles, as produções poéticas eram a expressão gratuita da alma, resultado de uma experiência não-mediada com o mundo. A harpa eólia, instrumento cujas cordas ressoam, sem necessidade da ação humana, por efeito da passagem de ar em uma caixa de ressonância, há muito é utilizada como metáfora para a inspiração poética: na acepção de inspiração que remonta a Demócrito de Abdera, a poesia também ressoaria como que motivada por forças externas, encontradas na natureza, não por força de um princípio interno da inteligência humana. Não é difícil de entender o porquê de essa ideia ter sido tão atrativa para os românticos, entrando em seu repertório de metáforas recorrentes pelo menos desde Coleridge (que escreveu o poema The AEolian Harp em 1795). ${ }^{10} \mathrm{O}$ humanizar da natureza surgia como necessidade para libertar o homem da "duração profana" (i.e. a temporalidade controlada de nosso cotidiano) através da imaginação e da intuição - assim o sujeito romântico passou a nutrir a aptidão de projetar novos mundos encantados nos quais o "tempo sagrado" do paraíso terrestre se restauraria (parafraseando ALMEIDA, 2012, p. 39).

\footnotetext{
${ }^{9}$ O ensaio em questão se chama Abhandlung über den Ursprung der Sprache (HERDER, 1978, p. 127-185, ver sobretudo, p. 171: "Quanto mais antiga e originária são as línguas, mais notável se torna tal analogia dos sentidos em suas raízes!"). A teoria em questão foi descreditada por etimólogos modernos, mas foi produtiva artisticamente: leitores históricos de Herder, de Goethe a Coleridge, buscaram reproduzir o suposto linguajar dos patriarcas da humanidade em sua lírica. A febre alemã pela poesia grega arcaica, em meados de 1770, foi acompanhada da noção que canções populares (Volkslieder) traziam uma qualidade pré-racional, "fundamentada em nosso vínculo comum de humanidade, e que expressa sua voz —a voz da humanidade [...] —, por meio da multiplicidade de línguas; elas evocam o divino, que é perceptível por todos aqueles que ainda confiam em suas sensibilidades" (MENGES, 2009, p. 198). Aqui temos o gérmen de teorias posteriores da 'cor local' e da idealização do homem primitivo - ele (e, na perspectiva dos alemães, os gregos arcaicos) seria detentor de algo que sabemos ter perdido dentro de nós.

10 Houve uma retomada da imagem em Goethe (Äolsharfen, 1822, além de várias passagens do Fausto), Machado de Assis (As brisas, 1864), Alexandre Herculano (O mosteiro deserto, 1838), além de Novalis, Eichendorff, Jean Paul, Herder, Gonçalves Dias, Mörike, Emerson, Brahms... Os exemplos são inúmeros.
} 
Mais tarde, Friedrich Schiller chamou esse caráter primevo, espontaneamente inclinado à poesia, de ingênuo (naïv), opondo ao caráter sentimental, repleto de anseio por perfeições inatingíveis dos modernos. ${ }^{11} \mathrm{O}$ neologismo que, mais tarde, batizou esse sentimento foi Sehnsucht. ${ }^{12}$ 'Ingênuo' e 'sentimental' foram categorias amplamente divulgadas no romantismo brasileiro; o maranhense Gonçalves Dias traduziu Schiller para o português ( $A$ Noiva de Messina, 1863), e o próprio Alencar (1846, p. 40) atesta conhecer o autor quando se refere a Wilhelm Tell (sobre recepção de Schiller no Brasil, ver VOLOBUEF, 2005).

O linguajar sugestivamente lírico dos parágrafos iniciais de Úrsula revela a mesma ambivalência: ele se aproxima da expressão primeva de modo a remeter, na chave da nostalgia, a um passado irrecuperável. A narrativa, assim, retoma programaticamente a ideia de cisão do homem com sua inocência que inaugura essa espécie de antropologia romântica, de forma a criar o quadro de harmonia que não dará o tom do restante do romance. A nostalgia, Firmina dos Reis chama de "melancholico enlevo" e "saudade" [tradução possível para Sehnsucht] que levam o homem primevo a entoar seu canto.

Trata-se de marcar a cisão com a ideia da 'cor local' e idealização vazia das virtudes brasileiras (como em Gonçalves Magalhães e Alencar), guiando a narrativa para uma segunda fatia de realidade, digamos, onde a natureza e as circunstâncias nativas, por mais esplendorosas que sejam, são incapazes de mitigar o sofrimento humano.

\section{DO ESTADO PRIMEVO AO UNIVERSO DA CAVALARIA: CAPÍTULO 1, PARÁGRAFOS 11-50}

Quando observado retrospectivamente, o segundo estágio de realidade em Úrsula está antecipado desde a primeira página do texto. A narrativa inicial descreve como o oceano não se comporta; as ondas não se erguem e não ameaçam quebrar limites impostos por um Deus regulador (remeto novamente a REIS, 1975, p. 7). O uso das negativas confere a impressão de que, em breve, esse quadro mudará, e de fato ele muda; doravante, a canção que brota

\footnotetext{
${ }^{11}$ Ver Über nä̈ve und sentimentalische Dichtung (1795). O trecho central: "Nem sequer a diferença de idiomas e épocas influem aí [na expressão de conteúdos intrinsicamente humanos da poesia arcaica], pois justamente essa unidade pura de sua origem e seu efeito [lhe] é característica [...] Algo muito diverso ocorre no caso do poeta sentimental [moderno]. Ele reflete sobre a impressão que os temas [Gegenstände] causam em si, e sua emoção tem fundamento unicamente nessa reflexão em que o poeta se transporta para fora de si e nos faz sermos transportarmos para além de nós mesmos. O tema, aqui, posiciona-se em relação a uma ideia, e sua força poética se baseia unicamente nessa relação. Assim, o poeta sentimental sempre tem que lidar com duas representações e sentimentos conflitantes, com a realidade com um limite e com sua ideia como o infinito; a emoção mista que surge aí sempre dará testemunha dessa dupla fonte" (SCHILLER, 1992, p. 739; o grifo é do autor).

12 "Saudade" foi o termo empregado por tradutores luso-brasileiros do século XIX para traduzir Sehnsucht. A tradução atual mais corrente do termo é "anseio" (ver comentário e considerações teóricas sobre o termo em SILVA, 2019a, p. 87-89).
} 
espontânea do peito do homem não mais sairá com facilidade, e a natureza não lhe parecerá tão mansa. O sol, antes abrasador, agora é "sempre ingrato, desdenhoso e cruel" (op. cit., p. 11 ); onde atuava, "dardejava seus raios sobre o infeliz mancebo" (p. 12; aqui temos nossa nova personagem, também chamada de 'cavaleiro', substituta do 'homem' primevo das páginas iniciais). Como os próprios termos explicitam, a narrativa dos parágrafos 11 a 50 do capítulo I nos joga ao universo ficcional do romance de cavalaria. Tal transição é indicada pelo uso de uma adversativa:

Entretanto em uma risonha manhan de agosto, em que a naturesa era toda galas, em que as flores eram mais bellas, em que a vida era mais seductora [....] um joven cavaleiro melancholico, e como que exhausto de vontade, atravessando porção d'um magestoso campo [...], deixava-se levar ao traves delle por um alvo e indolente ginete. Longo devia ser o espaço que havia percorrido; porque o pobre animal, desalentado, mal cadenciava os pesados passos [...] Que intensa agonia, ou que dôr intima lhe iria lá pelos abysmos da alma?! Só Deos o sabe! (REIS, 1975, p. 9-10, meu grifo).

A temporalidade da experiência extática de imersão na natureza - algo que Almeida (2012, p. 39) chamou de "tempo sagrado" - passa a se limitar pelo caráter de mundanidade próprio do tempo cronológico. A narradora é pontual: aquela é uma "manhan de agosto". A beleza tampouco funciona como expressão direta do encontro dos sentidos humanos com as representações; há um descolamento inédito entre o "magestoso campo" e a vida psíquica do protagonista: "Abstracto, ou como que mergulhado em penosa e profunda meditação, o cavaleiro prosseguia" (p. 10). Assim, a cena traz um novo estatuto epistemológico da vivência do mundo, para além dos imperativos da cor local ou idealizações do aborígene brasileiro. Apesar de agradável, aquele ambiente não minimiza a realidade do sofrimento.

Ao progredir a narrativa oferecendo um contraponto à ideologia ufanista de nosso romantismo, Firmina dos Reis relega seus predicados ao campo dos ideais ilusórios. Essa manobra exige que repensemos, já neste trecho, a interpretação corrente da fortuna crítica firminiana de que o início do romance, com sua descrição do sublime da natureza, serve meramente como marcador de estilo romântico (GÜNTHER; LOPES in: REIS, 2018, 11) ou ainda à criação de uma dualidade 'natureza boa versus sociedade ruim' (esta é tese de ZIN, 2018, p. 15; 2019, p. 59). O grande problema dessas interpretações é fazer com os leitores passarem reto pelas palavras cuidadosamente empregadas por Firmina.

Ao passo que os dez parágrafos iniciais chamam atenção para a natureza, doravante o cenário assume importância secundária. Aos poucos forma-se um outro universo marcado pelo conflito, e que determinará muito do roteiro do romance daqui em diante: "universo 
ficcional em que a donzela frágil e desvalida é disputada, ao mesmo tempo, pelo mocinho e pelo vilão" (ZIN, 2018, p. 14). Zin é certeiro quando alia o romance ao universo da cavalaria: temos nele o repertório completo com Tancredo surgindo como o cavaleiro virtuoso, Túlio como o escudeiro fiel, Comendador Fernando como o vilão perverso e Úrsula como a donzela virginal. Com a entrada do novo universo, mudam as regras do jogo: a liberdade subjetiva de cada uma das personagens estanques da cavalaria as leva a perseguirem seus objetivos a partir de um ânimo que as caracteriza como indivíduos propriamente ditos, descolados da natureza. Em suas Preleções sobre a estética (1835-1838), Hegel fornece uma chave para pensarmos a novidade que o romance de cavalaria trouxe para a poesia de povos cristãos: "a poesia não tem aqui nenhuma objetividade pressuposta diante de si, nenhuma mitologia, obras imagéticas e configurações que já estariam prontas diante dela para a sua expressão" (HEGEL, 2000, p. 291). As personagens não se mostram más ou virtuosas de antemão (como ocorre, por exemplo, quando já conhecemos a mitologia de um povo e o caráter de cada uma de suas personagens, independentemente da situação onde se encontram). Antes, a motivação individual deve ser provada para os leitores, cena a cena, através de ações pontuais. Daí a centralidade do heroísmo em narrativas da Idade Média; embora se espere dos heróis uma disposição heroica natural, o texto da cavalaria constitui-se de clímax em clímax por meio da descrição de complicações ao fim das quais o bem vence o mal. O produto ideológico das pequenas 'morais da história' - que derivam de cada batalha travada, de cada donzela salva dos usurpadores - é o código de honra cavaleiresco, a ideia de que a constância de valores e atitudes, a infalibilidade da força de vontade, constituem o herói. Desaparece de nosso horizonte a questão do vínculo com a natureza (HEGEL, 2000, p. 292-297). ${ }^{13}$

A cavalaria traz uma estrutura simples (ao menos em comparação com o romance moderno) por subsumir as relações entre personagens em um número simplificado de interações possíveis. Ama-se, odeia-se ou se é fiel ao outro — nada mais complicado ocorre aqui. A primeira ação do protagonista de Úrsula, o jovem que entra em cena sobre um cavalo, é exemplar dessa configuração. A cena conta como ele, desfalecido pelo Sol e pela angústia, cai ao lado de seu cavalo quando adentram um terreno acidentado.

\footnotetext{
${ }^{13}$ Safranski (2010, p. 120) interpretou o medievalismo de alguns românticos alemães como um desenvolvimento da velha ideia da Era de Ouro perdida. "Novalis escolhe a Idade Média cristã como imagem para criar um contraste. [...] Isto é a busca pelo tempo perdido, no espelho da própria infância e na infância da raça humana". A tradição do drama de cavalaria vem bem antes de Novalis: a primeira peça de sucesso de Goethe, Götz von Berlichingen (1771/1773), já explorou uma retomada idealizada da cavalaria e inaugurou um gosto por heroísmo, velhos castelos, batalhas de espada e campos de batalha sangrentos. Com ela surgiu uma rica tendência literária europeia (da prosa de Eichendorff e Tolkien à ópera de Richard Wagner) cuja ressonância se vê até hoje na cultura de massas — vide o seriado Game of Thrones e suas inúmeras ramificações.
} 
Cahio, e de um jacto perdeo o sentimento da propria vida; porque a queda lhe offendeo o cranea, e atturdido, e maltratado [sic] desmaiou completamente. [...] nenhuma esperança havia de que alguem socorresse o joven cavalleiro, [sic] que acabava de desmaiar. [...] N'esse comenos alguem despontou longe, e como se fora um ponto negro no extremo horisonte (REIS, 1975, p. 11-12).

O estranho avista o cavaleiro e o socorre. "O homem que assim falava era um pobre rapaz, que ao muito parecia contar vinte e cinco annos, e que na franca expressão de sua physionomia deixava adevinhar toda a nobresa de um coração bem formado" (p. 12). A honradez intuída da segunda personagem se prova na medida em que, tal qual o bom samaritano do Velho Testamento, sacia a sede do acidentado e o tenta reviver de forma desinteressada. "Só Deos testemunhava aquella scena tocante e admirável, tam cheia de unção e de caridoso desvelo!" (ver p. 14).

Essa fidelidade, Hegel a elencou como terceiro elemento formador do universo da cavalaria, ao lado da honra e do amor. Ela é uma constante já na poesia homérica, embora ali "concerne a um superior, que está acima, a um senhor" (HEGEL, 2000, p. 304). Na Antiguidade, portanto, o servo é fiel pois não se questiona hierarquias sociais: tal qual um ser desprovido de interioridade, ele serve por que alguém tem que servir. Na cavalaria, a fidelidade assume um tom diferente; Hegel fala de certa "autonomia subjetiva da fidelidade" que parte do caráter livre das personagens e, portanto, tem o mesmo valor das ações heroicas do cavaleiro. Por se tratar de uma mostra espontânea de caráter, a descrição das motivações puras é crucial em episódios de fidelidade entre dois amigos. É o que vemos na cena de salvação do enfermo em Úrsula: quando o convalescente acorda, trava um importante diálogo com seu salvador, cujas passagens mais reveladoras citamos:

_ "Quem és? [...] Porque assim mostras interessar-te por mim?!..."

_ " "...] supposto nenhum serviço vos possa prestar, todavia quisera poder ser-vos util. Perdoae-me!..."

— "Eu?" - atalhou o cavalleiro com effusão de reconhecimento — "eu perdoar-te! Podera todos os corações assimelharem-se ao teo." [...]

Este [quem salvou,] confundido e perplexo, religiosamente ajoelhando, tomou respeitoso e reconhecida essa alva mão [do cavaleiro], que o mais elevado requinte de delicadesa lhe offerecia, e com humildade tocante extasiado beijou-a.

Esse beijo sellou para sempre a mutua amisade que em seus peitos sentiam elles nascer e vigorar. As almas generosas são sempre irmans. [...]

- "Como te chamas, generoso amigo? Qual é a tua condicção?"

— "Eu, meo senhor [...], chamo-me Tulio. [...] A minha condição é a de misero escravo!" (REIS, 1975, p. 15-18). 
Aí surge o primeiro nome próprio do romance, após 58 parágrafos de narrativa. Esse momento da subjetivação inaugura, mais uma vez, um novo estatuto ontológico no romance: do universo da cavalaria - dos sentimentos puros, onde "as almas generosas são sempre irmans" - somos atirados no mundo histórico. Neste universo, há escravos e mestres, negros e brancos, homens e mulheres; estamos no Império do Brasil de 1859. Uma vez que o protagonista cai do cavalo (literalmente) adentrando o universo das dinâmicas sociais brasileiras, as antigas categorias relacionais se tornam mais complexas.

\section{A DIMENSÃO HISTÓRICA: CAPÍTULO 1, PARÁGRAFOS 51 EM DIANTE}

Os trechos seguintes descrevem o período de convalescença do cavaleiro. Túlio o carrega até um sítio da região, habitado por uma gente humilde apta a cuidar dos desvalidos. Ali entramos em contato com Úrsula, "ingenua e singela em todas as suas acções" (op. cit., p. 23). Úrsula é como as heroínas tradicionais dos romances sentimentais: sua atuação no mundo é reativa, mas isso porque sua posição social de órfã, pobre e solteira não dá abertura para qualquer papel social ativo. Retratá-la dessa forma, uma vez exposto o cenário de tensões sociais de 1859, é gesto de realismo. Pouco se fala, porém, de hierarquias naquele ambiente simples; como nos antigos idílios, todos vivem em pé de igualdade, preocupados em garantir o próprio sustento e cumprir suas tarefas.

$\mathrm{Na}$ verdade, é o cavaleiro, que logo descobrimos se tratar de um filho da classe dominante da região, o elemento desestabilizador naquele meio, regulador das atitudes de subserviência que passarão a determinar as atitudes de Túlio e Úrsula. O rapaz receberá um nome próprio a partir do capítulo IV, apenas (op. cit., p. 46), e, nesse ínterim, seguirá se comportando como uma personagem da ficção romanesca, acumulando atos de bravura que lhe são típicos. Em retribuição à amizade de Túlio, por exemplo, paga por sua alforria (op. cit., p. 30-31). Nem por isso deixa de ser seguido pelo negro, agora revertido em uma espécie de servo. $\mathrm{O}$ encontro entre as duas esferas da vida social maranhense engendra um descompasso entre os dois universos ali operantes: o membro da elite brasileira povoa um universo pautado pelas dinâmicas da dramaticidade: ele sofre pela antiga amada Adelaide (op. cit., p. 24), ${ }^{14}$ até que se apaixona pela moça que lhe serve de enfermeira durante seu período de convalescença (p. 43), Úrsula; vê-se acompanhado de seu fiel escudeiro Túlio; a antiga

\footnotetext{
${ }^{14}$ Nome de origem franco-germânica, comum na nobreza medieval europeia; Adelheid também é o nome da primeira femme fatale da literatura alemã, amada de Weislingen no principal drama de cavalaria do préromantismo alemão, o já citado Götz von Berlichingen de J. W. Goethe. Como a Adelaide firminiana, atua como uma completa megera e manipuladora.
} 
noiva roubada por seu próprio pai, no episódio bizarro do capítulo VII, remete a cenas de complicações sucessórias próprias da nobreza medieval, não a um evento próprio do mundo moderno (p. 68 et seq).

Uma vez que surge esse terceiro estatuto ontológico, digamos, do romance - a vida real do Brasil Império - vemos a narrativa oscilar entre as antigas convenções da cavalaria e uma realidade menos centrada em atos de bravura e virtude que guiam os caminhos do jovem. Curiosamente, a narradora, sempre quando quer remeter ao universo de fantasia alienante de Tancredo, retoma os antigos nomes da cavalaria:

o cavalleiro, deslisando um fraco sorriso, estendeo a mão á donzela, e disselhe com reconhecimento:

- Ah! Senhora, como sois boa! Quem quer que sejais, acceitai meos sinceros agradecimentos pelo generoso interesse, $[\mathrm{sic}]$ que mostrais por um infeliz desconhecido (REIS, 1975, p. 25).

Tal alternação de nomes, sugiro, _ 'Tancredo' e 'Úrsula' quando lidamos com o mundo real, 'cavaleiro' e 'donzela' quando retornamos à fantasia - estabelece uma flutuação constante durante a narrativa. $\mathrm{O}$ universo que motiva as personagens, o romântico-idealista, está em constante tensão com uma realidade alheia a seus anseios. Todos os fundamentos do mundo heroico medieval e seus códigos são gradualmente desvalidados, pois ao fim a realidade ruim vence: este é um romance onde todos acabam assassinados, traumatizados ou enlouquecidos.

Aqui, mesmo a união mística com o Divino, característica do homem primevo da abertura do romance, foge das personagens em momentos de necessidade. No capítulo XIII, Úrsula se encontra no cemitério, ao lado do túmulo da mãe. Ela foge de seu próprio tio, um rico fazendeiro da região que persegue mocinhas indefesas e espanca escravos por prazer; o vínculo com a mãe lhe resta como "único élo, $[$ sic $]$ que ainda a prendia à cadeia da vida" (p. 126). Os termos empregados para descrever a busca por um consolo místico na fé são precisos: "Os olhos da donzella levantavam-se para esse sagrado estandarte da Fé; porque o coração procurava um auxilio do céo; mas logo a cabeça pendia para a terra, e os lábios roçavam o pó da campa" (p. 127). A religiosidade em si é alterada pelo estatuto de realidade; não há ligação direta entre o humano e o divino. Este contempla o sofrimento da moça ("ninguem lhe prestava o minimo soccorro, e Deos somente a via, e avaliava a grandesa das suas dores”, p. 127-128) e, no máximo, serve de alento momentâneo à sofredora. Por fim, Úrsula é encontrada desfalecida sobre o túmulo da mãe, seus salvadores são Túlio e Tancredo.

Os repetidos atos de salvação surtem efeito por pouco tempo. Para a proteção de 
Úrsula, põem-na em um convento - este refúgio último do mundo das relações humanas (capítulo XI) —, enquanto lá fora trava-se uma guerra cujo prêmio será sua virgindade. Esse é momento de contextualização das nervuras da sociedade escravista e patriarcal, das múltiplas contradições que a compõe e que tanto tem chamado atenção de pesquisadores de Brasil - a primeira descrição brasileira da passagem transatlântica, prévia ao poema Navio Negreiro (1868) de Castro Alves, aqui se encontra (ver ZIN, 2019, p. 64-68), além de um estudo detalhado de métodos de controle de escravos, que mediante chantagens, vantagens pessoais e ameaças, os levam a traírem uns aos outros.

Toda essa parcela do romance é de suma importância na medida em que atesta a falência do mundo das virtudes românticas em pleno início de romantismo brasileiro. A manipulação do horizonte de expectativas de leitores românticos — em relação tanto aos clichês da cavalaria quanto aos conteúdos inovadores - é magistral, embora sutil. Sutileza é uma das virtudes de Firmina dos Reis, e faz leitores que acreditaram na falsa modéstia de seu prólogo perderem o fio da meada de seu texto desde o início.

Notemos como a realidade desvalida os ideais: antigas virtudes cavaleirescas ganham contornos de delírios, os mesmos que inicialmente aplacaram Tancredo em sua fase de convalescença: “Ao delírio violento seguio-se plácida hallucinação:-parecia que um mundo de gratas ilusões, povoado de meigos seres, o afagava [...]” (op. cit., p. 27, meu grifo). Os termos são claros: aquele mundo não existe. No mesmo contexto inicial de delírio, temos um longo monólogo de Tancredo sobre a escravidão, algo que só poderia sair da boca de um homem da elite imperial.

Oh! A mente! Isso sim ninguém a pode escravizar! [...] a alma está incerrada nas prisões do corpo! Ella chama-o para a realidade, chorando, e o seo choro, só Deos comprehende! Ella, não se pode dobrar, nem lhe pesam as cadeias da escravidão; porque é sempre livre [...] (REIS, 1975, p. 28).

Esta é uma das passagens mais citadas do romance, tida como uma espécie de profissão de fé antiescravista (ver, por exemplo, TELLES, 1989, p. 77). Na verdade, não se trata de uma afirmação da narradora, mas das facetas da alienação de Tancredo, como o trecho seguinte explicita: "Tinha no entanto terminado o delírio ao doente: segui-se-lhe extrema prostação e um suor geral e frio" (idem). Eis porque o trecho é problemático: na prática, tanto importava a liberdade do pensamento: a missão de qualquer abolicionista é destruir a escravidão de uma vez por todas e, se possível, enterrar os escravocratas com ela. Satisfazerse com ideias românticos de 'liberdade do pensamento' é parte do problema que, 
historicamente, atrasou a emancipação coordenada dos escravizados (essa é uma ideia central dos abolicionistas mais radicais nos EUA, de David Walker a Harriet Tubman; ver SILVA, 2019, p. 56-61). Frente às propostas reais que guiaram o movimento abolicionista internacional ao êxito, a frase de Tancredo não passa de um idealismo vazio. Esse idealismo é tão débil frente à violência dos processos históricos que, em ocasião narrada no capítulo VII, Tancredo se vê na obrigação de voltar à casa dos pais para velar a mãe recém-falecida. "A dor [...] crescia, e suffocava-me a proporção que me aproximava dessa casa [...] o aspecto lugubre do escravo, [sic] que vigiava a entrada, aumentou mais essa dôr profunda" (REIS, 1975, p. 68). Em outras palavras: Tancredo vem de uma família de escravistas; sobrevivesse ele ao final do romance, seria herdeiro de corpos sequestrados. Seu abolicionismo não passa de um palavrório vazio.

Esta é uma das marcas que atestam a falta de contato com a realidade, doando às atitudes do cavaleiro algo de ridículo. Enquanto os outros trabalham, ele salta de um delírio para o outro; relembra de seus antigos amores por Adelaide e, quando recobra um pouco da lucidez, declara-se apaixonado pela bela Úrsula, para então voltar a ter mais uma recaída (p. 21-38). No novo momento do romance, o da vida real, alguém interessado em viver fiel aos ideais da cavalaria não passa de um desvairado. Hegel, mais uma vez, analisou a dissolução histórica da cavalaria no cômico, quando Cervantes cria a figura de Dom Quixote como mais autêntico dos cavaleiros medievais, tornado ridículo em função do fato que o mundo à sua volta mudou:

Dom Quixote é um ânimo completamente seguro na loucura de si mesmo e de sua causa, ou muito mais é esta apenas a loucura, o fato de ele ser e permanecer tão certo de si e de sua causa [...] Igualmente toda a obra é, por um lado, uma troça da cavalaria romântica, [...] mas, por outro lado, os acontecimentos de Dom Quixote serão apenas o fim com o qual se entrelaçam de modo ameno uma série de novelas autenticamente românticas, para mostrar conservado em seu verdadeiro valor o que a parte restante do romance dissolve de modo cômico (HEGEL, 2000, p. 327).

Este gesto é aquilo que Safranksi (2010, p. 57) chama de "fantasia romântica da libertação", o querer "retroceder a fragmentação da vida" pela própria vontade, como se a imaginação regulamentasse a vida real. Os privilégios de Tancredo permitem-no se refugiar nesse tipo de fantasia delirante. Nesse sentido, Úrsula é a sua contraparte. Não há fantasia romântica de libertação em seus discursos; ela é uma mulher desenganada pela própria condição social desfavorável. Pensemos o início de crise existencial: a depressão de Úrsula começa muito antes da perseguição sexual do tio, Fernando B.; ela começa com a perspectiva 
de um vínculo amoroso com Tancredo:

Ursula, pelo contrario, sentia extranho desaçocego, um que, que não sabia definir a si própria! Uma inquietação mortal, uma desconfiança, e as lagrimas brotavam-lhe espontâneas do coração [...] $O$ que é a natureza humana! O que é o coração da mulher! (REIS, 1975, p. 24; meu grifo).

O fato de aqui termos uma modulação de "Meu amigo, o que é o coração do homem!", a frase da abertura d'Os Sofrimentos do jovem Werther de Goethe, ${ }^{15}$ permite que nos aventuremos em um exercício comparativo com uma das crises existenciais mais famosas da literatura. Tanto Werther quanto Úrsula vivem a angústia dos seres altamente imaginativos a vivência de suas subjetividades se define pelo vacilar entre a dimensão da liberdade pessoal e das imposições do mundo exterior. ${ }^{16}$ Mas por quê a aparição de Tancredo a leva a mais uma crise? Pois Úrsula não acredita no amor idealizado da cavalaria. À luz do solilóquio que declama no capítulo III (op. cit., p. 34 et seq), embora "sentia a necessidade de uma alma, [sic] que compreendesse a sua”, sabia que aquela era uma união impossível. Mesmo assim segue os rituais do namoro de forma pragmática, como uma órfã de pai cuidando da mãe enferma: para ela o casamento significaria uma redenção financeira.

Seu namorado, por sua vez, mostra certa consciência das contradições por trás da união. Ele não pede que Úrsula o ame: pede que sua alma simpatize com a dele (como lemos no capítulo III, p. 38). Ela não afirma o amar, mas que aprenderá a nutrir-lhe afeto. O acordo é executado em um nível de estrito pragmatismo que, apesar de sua objetividade, malogra uma vez que a família de Tancredo entra em cena (capítulo VII em diante). Os temores de Úrsula se confirmam: não há chances de o casal terminar junto, rompendo as barreiras de diferenças sociais e passando a viver com base no evangelho do coração enquanto aquela estrutura familiar não ruir.

Resta-nos responder: em que medida Úrsula é um romance antiescravista? Apesar de não ser virulento ou propor qualquer perspectiva de manumissão, o romance é inovador em um nível caracterológico: Túlio, preta Susana, Antero são todas personagens cativas tratadas com devida dignidade (TELLES, 1989, p. 77-78; SIMÕES, 2012, p. 14): Susana é a pessoa mais sóbria do romance; Túlio é um autêntico cavalheiro, irmão espiritual de Tancredo e confidente de Úrsula. Os escravistas, por outro lado, agem feito sociopatas (Fernando B.) ou

\footnotetext{
15 "Bester Freund, was ist das Herz des Menschen!" (GOETHE, 2006, p. 10).

${ }^{16}$ Não por acaso, Firmina dos Reis está a todo momento variando no emprego de termos semanticamente ligados a "limitações": ela fala de "amarras", "elos", "laços", "cadeias" para descrever os sentimentos de Úrsula. O linguajar de Werther, igualmente, é repleto de termos semelhantes: Einschränkung e derivados (16 ocorrências no curto romance), além de Kette, Hindernis e termos afins.
} 
isentos obcecados com os próprios desejos (Tancredo). Nesse contraste se cria uma empatia inédita na literatura brasileira; o gesto de Maria Firmina é aquele que "humaniza o oprimido e animaliza o opressor" (ZIN, 2019, p. 84) e — adicionemos — torna ridículo os que se isentam dos imperativos históricos.

Essa intervenção sutil, sobretudo em um país de literatura abolicionista escassa (TELLES, 1989, p. 75), é o ponto de chegada relevante do projeto romântico de Firmina dos Reis, uma resposta às demandas ideológicas do romantismo brasileiro. Em vez de ecoar o "Minha terra tem palmeiras" da poesia ufanista de Magalhães, perdendo-se em divagações vácuas sobre a beleza de nossa natureza, Firmina denuncia: sua terra tem Palmares. ${ }^{17} \mathrm{O}$ nacionalismo realmente progressivo de nossas letras é aquele que encara o Brasil dentro de seus processos históricos, sem medo de desvelar suas contradições.

Embora Firmina meramente insinue ideias da antiescravidão em Úrsula, é convincente na formulação de uma estética própria. A autora viveu 95 anos, lembremos; o desenvolvimento das ideias incipientes em Úrsula deve ser acompanhado tendo em vista o momento em que surge, em seu pensamento e nos círculos sociais maranhenses, a consolidação de propostas concretas para a abolição. Nesse sentido, Zin (2019, p. 79 et seq) identifica um importante momento de virada só na década de 1880, com a publicação do conto "A Escrava", o qual deverá ser tema de um ensaio futuro.

\section{CONCLUSÃO: MARIA FIRMINA DOS REIS NA CONTRAMÃO DO UFANISMO BRASILEIRO}

É absolutamente correto que não estamos conectados com a história de nosso povo. Mas por que isso é assim? Porque essa história foi sem resultado, porque não podemos nos considerar produto de seu processo orgânico como, por exemplo, podem fazer os ingleses e os franceses, porque isso que certamente devemos chamar de nossa história não é nossa história de vida, mas sim de nossa doença, que ainda hoje não nos conduziu à crise. FRIEDRICH HEBBEL

Nossa conclusão parte de uma nota sobre a metodologia aqui empregada: compreensões contemporâneas de intertextualidade mostram como todo "texto é um intertexto", não precisando ser visto como uma unidade inerte; ele é em si um proliferador de significados sociais (SCHMELING, 2013, p. 149-150) - isso se conclui dado que autores são seres que adquiriram linguagem, discurso, estilo e ideias da sociedade e de textos que os

\footnotetext{
${ }^{17}$ Para lembrarmos a inversão de Oswald de Andrade no poema Canto de regresso à pátria (1927).
} 
formaram. Desde a estética do romantismo sabemos que "somos feitos de literatura", ou ao menos nossas ideias se constituem de discursos calculados para gerar um efeito (SAFRANSKI, 2010, p. 50).

A ideia da intertextualidade provou-se fértil por revelar facetas até então ignoradas de produtos literários. A partir daí tornou-se regra de ouro de comparatistas enxergar citações de um autor ao outro como chaves de interpretação em potencial. Menções a outros autores, seja elas diretas ou não, são formas como doam a seus textos relações semânticas amplificadas, de modo que podemos abrir um livro como Úrsula e vê-lo como uma malha de referências e caminhos interpretativos latentes. De um ponto de vista da literatura comparada, o fato de Firmina dos Reis se valer de palavras-chave da teoria romântica logo nos primeiros parágrafos de seu texto - "sublime" (referente ao Erhabene de Kant), ou "saudade" (referente ao Sehnsucht de Novalis) — obriga-nos a considerar o potencial referencial das mesmas. O uso dos termos, sobretudo quando é coerente com as teorias que o sustentaram em textos estrangeiros de filosofia e literatura, revelam uma face da maranhense como dona de um repertório cultural até então minimizado por sua fortuna crítica.

O problema central desse tipo de análise comparatística é que ela se desenvolve no campo da especulação. Úrsula é repleto de supostas referências intertextuais a Os sofrimentos do jovem Werther de Goethe, a Shakespeare, a Herder e a Schiller — mas também contém referências explícitas das quais não nos ocupamos neste artigo, embora corrobore com uma de suas teses centrais: a de que a descrição da natureza em Firmina dos Reis é um dispositivo complexo, mediante o qual a autora se situou ante a proposta ufanista do primeiro romantismo brasileiro. Lemos no capítulo XIII:

[...] era uma d'essas tardes, [sic] que só Bernardin de Saint-Pierre soube pintar no delicioso Paulo e Virginia, que deleita a alma, e a transporta a essas regiões aereas, $[s i c]$ que só a imaginação comprehende, e que divinizando as nossas ideias, nos torna superiores a nós mesmos (REIS, 1975, p. 124).

A única referência direta em Úrsula a outro autor é justamente ao escritor rousseaniano tardio, autor de um romance abolicionista, que Firmina provavelmente leu no original ou na tradução portuguesa de 1806, pela Typografia Rollandiana de Lisboa. ${ }^{18}$ Esse 'mestre da genuína poesia', segundo Madame de Stäel, teve como principal projeto de vida elaborar um linguajar poético de descrição da natureza na literatura francesa. No prefácio da

${ }^{18}$ É possível conjeturá-lo devido ao fato de que a tradução brasileira (pela Impressão Régia do Rio de Janeiro, 1811) não trazia o nome do autor; ali, o texto integrou como parte de uma antologia de prosa francesa. A este respeito, ver o estudo de Sales (2004, p. 184). 
tradução britânica de Paul et Virginie, Sarah Jones explica a gênese da ideia:

os termos para descrever a natureza ainda não haviam sido inventados. "O esforço", ele diz, "de descrever uma montanha de tal maneira que ela pudesse ser reconhecida. Quando você fala da base dela, de seus lados, de seu cume, já disse tudo! Mas que variedade pode ser encontrada naquelas formas dilatadas, alongadas, achatadas ou cavernosas! Só por perífrase elas podem ser expressas. A mesma dificuldade existe no caso de planícies e vales. Mas se você tiver de descrever um palácio, não há mais qualquer dificuldade. Cada uma de suas formações tem seu nome apropriado" (JONES, 1893, p. XXVI). ${ }^{19}$

A missão que Saint-Pierre lança para seus contemporâneos é a de desenvolver, para a natureza, um linguajar tão exato quanto o da arquitetura. Como romântico, não é um mistério deduzirmos de onde veio tal interesse pela exatidão linguística; Saint-Pierre compartilha a mesma ânsia de Werther de querer reproduzir a totalidade da natureza, agora em prosa francesa. Suas propostas para empreender tal inovação foram registradas no longo ensaio Etudes de la nature (1784), que hoje vale mais como uma curiosidade histórica dos interesses expressivos dos poetas românticos do que propriamente como um manual de estilo. Ainda estão para ser escritos os artigos que deem conta de explorar o quanto de Saint-Pierre era conhecido por Firmina dos Reis - nossa pretensão aqui é somente a de apontar um caminho de pesquisa e sugerir que, se Firmina escolhe Saint-Pierre como aquele cuja prosa nos "transporta a essas regiões aereas, [sic] que só a imaginação comprehende", é porque tinha consciência da multiplicidade de usos da descrição da natureza dentro do projeto romântico internacional. A questão não era tão simples como Gonçalves de Magalhães e José de Alencar a haviam pensado.

Ambientes em Úrsula não possuem valor por si só, mas são refletores da cultura dos homens. O branco da elite percorre o mundo como se fosse um cavaleiro em sua armadura, enquanto o negro e a mulher pobre levam suas existências sob constante ameaça, padecendo ao fim à tirania de Fernando, o primeiro vilão escravista da literatura brasileira. Por fim, a realidade destrona o herói, negando-lhe qualquer possibilidade de êxito naquele mundo desajustado: todos terminam assassinados ou ensandecidos. O Brasil da cor local é substituído, em Úrsula, pela realidade em crise que ainda esperava por resolução: seu cenário é o da história como palco de realizações da humanidade, do experimento mundi cujas regras

\footnotetext{
${ }^{19}$ No original: "the terms for describing nature are not yet invented. "Endeavour," he says, "to describe a mountain in such a manner that it may be recognised. When you have spoken of its base, its sides, its summit, you will have said all! But what variety there is to be found in those swelling, lengthened, flattened, or cavernous forms! It is only by periphrasis that all this can be expressed. The same difficulty exists for plains and valleys. But if you have a palace to describe, there is no longer any difficulty. Every moulding has its appropriate name."
} 
vinham sendo negociadas entre escravistas incorrigíveis (Fernando e seus capatazes), brancos avessos à ideia da escravidão, mas situados à margem do discurso abolicionista (Úrsula, Tancredo) e os negros (Susana, Túlio, Antero). O resultado final do que neste artigo chamei de 'terceira camada de realidade' é a crise. Uma crise que, historicamente, ainda estava por ser resolvida com a abolição da escravatura e que, então, ainda não havia acontecido.

A americanística vem aprendendo aos poucos, desde os anos 1970, que um panorama mais amplo do romantismo estadunidense é incompleto se desconsidera a produção de autores negros de Venture Smith a Harriet Ann Jacobs: muitos dos quais fugiram do cativeiro, se educaram e criaram uma cultura de denúncia social que alterou para sempre as formas de fazer literatura e filosofia naquele país. A crítica da sociedade escravista não surgiu ali como um ato espontâneo, mas com o desenvolvimento de teorias, de topói e de uma retórica meticulosamente calculada, ancorada no discurso literário em voga na época: o do romantismo e do idealismo filosófico. ${ }^{20}$ A maior lição tirada dessa experiência é que uma leitura dos romantismos das Américas que não dê lugar de destaque para seus autores abolicionistas é um erro grosseiro - tanto no Brasil quanto nos EUA, a escravidão foi a grande questão do século XIX, sobretudo quando pensamos naquela como uma época em que a já conhecida libertação de amarras estéticas das artes foi indissociável da busca pela emancipação do gênero humano. Maria Firmina dos Reis, em partes por sua condição marginal de mulher afrodescendente no Império, em partes por mérito individual, provou-se resistente às discussões infrutíferas da 'cor local' de seus contemporâneos Magalhães e Alencar - sua missão, porém, não foge da missão romântica internacional, interessada em captar e expressar a vida real, de forma aberta e amplificadora de sentidos. Se nossa tese é correta, seu romantismo provou-se mais apto na tarefa de representação da realidade, fazendo da autora uma espécie de "matriz explicativa do Brasil oitocentista" (os termos são de Miguel Wady Chaia in ZIN, 2019, p. 2). Herdeiros dessa tradição crítica, para além dos desvarios ufanistas, serão ninguém menos que Machado de Assis e Lima Barreto. Esperamos que chegue a vez dos estudos literários mostrarem que, dentro de nossa produção oitocentista, autores abolicionistas e seus precursores merecem ser tratados como os formadores da inteligência brasileira.

\section{REFERÊNCIAS BIBLIOGRÁFICAS}

ALENCAR, José de. Cartas sobre a Confederação dos Tamoyos: publicadas no diario. Rio

\footnotetext{
${ }^{20}$ Sobre o desenvolvido de argumentos abolicionistas nos EUA por 150 anos, de 1688 às vésperas da Guerra da Secessão, ver artigo de Silva (2019b).
} 
de Janeiro: Empreza Typ. Nacional do Diario, 1856.

ALMEIDA, Ana Maria de. Elementos arquetípicos em A Nebulosa de Joaquim Manuel do Macedo. O eixo e a roda, v. 21, n. 1, 2012, p. 27-56.

CARNEIRO, Vinícius Gonçalves. Entre a crítica e a nação: Cartas de Alencar sobre a Confederação dos Tamoios. Anais do X Seminário de História da Literatura, Porto Alegre, 2011. p. 497-504.

GOETHE, Johann Wolfgang von. Die Leiden des jungen Werthers - Die Wahlverwandtschaften - Kleine Prosa - Epen. Frankfurt am Main: DKV, 2006.

Os Sofrimentos do Jovem Werther. Tradução de Marcelo Backes. Porto Alegre: L\&PM Editores, 2001.

HEGEL, Georg Wilhelm Friedrich. Cursos de Estética. Volume II. Tradução de Marco Aurélio Werle. São Paulo: UNESP, 2000.

HERDER, Johann Gottfried. Abhandlung über den Ursprung der Sprache. In: MÜLLER, Peter (Hrsg.) Sturm und Drang. Weltanschauliche und ästhetische Schriften. Band 1. Berlin / Weimar: Aufbau Verlag, 1978, p. 127-185.

JONES, Sarah. Memoir of Bernardin de St. Pierre. In: SAINT-PIERRE, Bernardin. Paul and Virginia. London: W. S. Orr \& Co., 1839, p. IX-XXIX.

LACOUE-LABARTHE, Philippe; NANCY, Jean-Luc. The Literary Absolute. The theory of literature in German romanticism. Albany: SUNY Press, 1988.

MAGALHÃES, Domingos José Gonçalves de. Estudos sobre a História da Literatura. São Paulo: Academia Paulista de Letras, 1978, p. 132-159.

MAGALHÃES PINTO, Ana Flávio. A atualidade de Maria Firmina dos Reis, ou uma escritora negra do seu tempo. In: REIS, Maria Firmina dos. Úrsula. Porto Alegre: Taverna, 2018, p. 215-230.

MENGES, Karl. Particular Universals: Herder on National Literature, Popular Literature, and World Literature. In: ADLER, Hans \& KOEPKE, Wulf (ed.). A Companion to the Works of Johann Gottfried Herder. Rochester: Camden House, 2009, p. 189-214.

NIEDERMEIER, Michael. Dilettantismus. In: DAHNKE, H.; OTTO, R. Goethe Handbuch. Band 4/1. Stuttgart: J. B. Metzler Verlag, 2004, p. 212-214.

PERRONE-MOISÉS, Beatriz; SZTUTMAN, Renato. Notícias de uma certa Confederação Tamoio. Mana, vol. 16, n. 2, p. 401-433, 2010.

PREISENDÖRFER, Bruno. Als Deutschland noch nicht Deutschland war: Reise in die Goethezeit. Berlin: Galiani-Berlin, 2015.

REIS, Maria Firmina dos. Ursula. Romance original brasileiro. Edição Fac-similar. Prólogo e org. de Horácio de Almeida. São Luís: Governo do Maranhão, 1975. 
Úrsula. Porto Alegre: Taverna, 2018.

SAFRANKSI, Rüdiger. Romantismo: uma questão alemã. São Paulo: Estação Liberdade, 2010.

SALES, Germana Maria Araújo. Produção e tradução no Brasil oitocentista: breve histórico. Atas do XIX Congresso Nacional da ANPOLL, 2004, Maceió, v. 1. p. 184.

SCHMELING, Manfred. Einfluss und Komparatistik. In: ZYMNER, Rüdiger; HÖLTER, Achim (Hrsg.) Handbuch Komparatistik: Theorien, Arbeitsfelder, Wissenspraxis. Stuttgart: J. B. Metzler, 2013, p. 149-151.

SILVA, Felipe Vale da. Três paradoxos para entender Novalis. In: NOVALIS [Friedrich von Hardenberg]. Hinos à Noite. São Paulo: Sebo Clepsidra, 2019a, p. 74-96.

Gênese e estratégias da mídia abolicionista estadunidense. Do panfleto à narrativa de escravos (1688-1829). Humanidades \& Inovação (UNITINS). Vol. 6, no. 4, 2019b, p. 4962.

SIMÕES, Bárbara. A escrita de Maria Firmina dos Reis: soluções para um problema existencial. Rio de Janeiro: Fundação Biblioteca Nacional, 2012.

SCHILLER, Friedrich. Theoretische Schriften. Frankfurt am Main: DKV, 1992.

TELLES, Norma. Escritoras, escritas, escrituras. In: PRIORE, Mary Del (Org.). História das mulheres no Brasil. São Paulo: Contexto, 1997, p. 401-442. 1989, p. 73-83.

Rebeldes, escritoras, abolicionistas. Revista de História. São Paulo, n. 120, jan./jul.,

VOLOBUEF, Karin. Friedrich Schiller e Gonçalves Dias. Pandaemonium Germanicum, Vol. 9, 2005, p. 77-90.

ZIN, Rafael Balseiro. Úrsula, 'romance original brasileiro'. In: REIS, Maria Firmina dos. Úrsula. Porto Alegre: Taverna, 2018, p. 13-32.

Maria Firmina dos Reis: a trajetória intelectual de uma escritora afrodescendente no Brasil oitocentista. São Paulo: Aetia Editorial, 2019. 